\title{
Corporate risk disclosure by UK firms: trends and determinants
}

\author{
Bassam Rajab \\ School of Accounting, Economics and Statistics, \\ Napier University Business School, \\ Edinburgh Napier University, Edinburgh EH14 1DJ, UK \\ E-mail: b.rajab@napier.ac.uk
}

\section{Morrison Handley-Schachler}

Teesside Business School, University of Teesside, Middlesbrough, Tees Valley, TS1 3BA, UK

E-mail: m.handley-schachler@tees.ac.uk

${ }^{*}$ Corresponding author

\begin{abstract}
This study explores risk disclosure practice using content analysis of 156 annual reports prepared by 52 UK listed companies in three different periods $(1998,2001$ and 2004). The study relates the extent of risk disclosure to firm-specific characteristics. The study found, a trend of increasing amounts of risk disclosure in the annual report over the six-year period influenced by accounting regulation and accounting institutes' recommendations. US dual listing and involvement in heavy industry are significantly and positively correlated with the level of risk information disclosed by the sampled companies. Risk disclosure is not related to size or leverage.
\end{abstract}

Keywords: risk disclosure; corporate disclosure; dual listed companies.

Reference to this paper should be made as follows: Rajab, B. and Handley-Schachler, M. (xxxx) 'Corporate risk disclosure by UK firms: trends and determinants', World Review of Entrepreneurship, Management and Sustainable Development, Vol. x, No. x, pp.xxx-xxx.

Bibliographical notes: Bassam Rajab completed his $\mathrm{PhD}$ in Accounting at Napier University in 2008, having previously studied and taught Accounting at the Faculty of Commerce at the Islamic University of Gaza and then studied Accounting and Finance at Napier University. His research focuses on examining risk reporting in corporate UK.

Morrison Handley-Schachler was awarded a DPhil in Ancient History at Oxford University in 1993. He subsequently worked as an auditor, with the Audit Commission in England and later with Scott-Moncrieff in Edinburgh, becoming a member of the Chartered Institute of Public Finance and Accountancy in 1998. He became a lecturer in Accounting at Napier University in 2000 and Principal Lecturer in Fraud and Financial Crime at the University of Teesside as a in 2008. He has published papers, jointly or as sole author, on ancient Iranian religions, Chinese accounting history, public sector risk management, corporate governance and trade emerging markets. 


\section{Introduction}

The last 15 years have seen dramatic changes in the business environment driven by fundamental developments in technology, society and world politics. The evolution of new technology especially has facilitated the expansion of businesses as well as the globalisation of capital markets. While such changes were necessary for businesses' growth and expansion, they have, however, created many challenges and concerns. Business transactions and structures have become more complex. Trading conditions have also become (and remain) very tough and competitive with new businesses emerging all the time. The rise in stock return volatility worldwide together with an increase in economic, political and regulatory uncertainty around the globe was also a concern. At the same time, the business scandals of the late 20th and early 21 st century (e.g., Maxwell, Equitable Life, Enron, WorldCom, AIG, Lehman Brothers, Madoff) have shaken the confidence of investors and regulators. The survey of UK investors conducted by Cavendish Asset Management (2002) found that two thirds of UK investors no longer feel confident investing in the stock market as a result of fraud and accounting problems at Enron and WorldCom. Since then investors' confidence has been further shaken by the scandals in the use of high risk investment vehicles such as securitised mortgages by large financial institutions.

It is perhaps doubtful whether it would be possible for corporate accountants to put across the full complexity of an actuarial analysis of the risks and probable outcomes attending instruments such as Equitable Life's guaranteed annuities, which gave rise to very uncertain outcomes in terms of liabilities which were affected not only by stock market returns but also by unknowns such as future life expectancies. Likewise, even leaving aside deliberate attempts to mislead, the expression of fair values for Enron's energy supply contracts or WorldCom's communications networks would inevitably have involved substantial problems in expressing risks and uncertainties to readers of accounts. Although such uncertainties may be expressible, the limited time available to investors for the analysis of accounts would be likely to nullify the usefulness of some of this risk reporting. In addition, the expression of very great uncertainties about future events would be likely to leave investors in a position in which they are really being invited to take a partially informed guess at the fair value of assets and liabilities, rather than being able to make reasoned estimates and quantify the probabilities of different levels of variance from those estimates. Nonetheless, the increasing impact of risk factors on which investors feel they have been misinformed or of which they feel they were not apprised, leads to an increasing demand for fuller information on risks of which managers of the corporation is aware.

The presence or absence of risk information on which investors feel confident in basing investment decisions therefore has the potential to affect capital flows, not only from financial institutions investors and private investors to industrial companies, whether large, medium or small, but also between private investors and financial institutions whose ability to manage financial risk effectively can be called into question by events such as the sub-prime lending crisis of 2007-2008. Therefore improved risk reporting has at least the potential to contribute to a more stable environment for investment activity and capital accumulation.

With these episodes in the business and investment environment in mind, there has been a rise in the attention and interest of investment regulators, accounting standard setters, stock markets, accounting institutes and firms and credit rating agencies 
worldwide in the quality of financial reporting, including risk reporting. Regulators around the world have been actively considering how to promote better disclosure by listed companies in order to increase transparency of financial reporting hence restore investors' confidence, especially by encouraging disclosures which will give investors and others a clearer idea of the risks faced by corporations. It might be anticipated that companies which raise capital through stock-market listings would increase their risk disclosures in order to reduce their cost of capital. This paper represents an effort to examine changes in the level of risk disclosure in corporate annual reports.

The remainder of this paper is structured as follows: Section 2 reviews corporate reporting and risk disclosure literature, covering its requirements and recommendations, and its motivations and benefits. Research hypotheses are developed in Section 3. Section 4 describes the selection of the sample and research method. Section 5 presents the results and hypothesis testing. Section 6 discusses the results and Section 7 presents our conclusions and makes suggestions for future research.

\section{Literature review}

\subsection{Corporate reporting: the disclosure gap and motivation for change}

The rapid pace of change in the business environment has forced companies to use new types of information to manage their businesses. Many companies have adopted new performance measures for internal reporting purposes, such as those developed in the framework of the Balanced Scorecard (Kaplan and Norton, 1996). With regard to risk, various risk management methods have evolved over time. Companies have learnt to use sophisticated techniques to quantify and monitor risk effectively, thus reducing the quality gap in internal risk management systems. However, companies' external reporting at the turn of the century was perceived as lacking an adequate disclosure on risk and uncertainties (Cabedo and Tirado, 2004). The American Institute of Certified Public Accountants (AICPA, 1987) stated that the users of financial statements are increasingly demanding more information to help them assess risk and uncertainties. Schrand and Elliott (1998) summarised and documented the debate held in the 1997 AAA/FASB conference on risk reporting by companies to their stakeholders. They suggest that US companies were not providing sufficient information, related to risk, in their annual reports. In addition, there has been a growing perception that financial reporting standards developed by bodies such as the International Accounting Standards Board (IASB) and the UK's Accounting Standards Board (ASB) or those developed from civil law codes in continental Europe fell short of meeting all the information needs of all users. Previous disclosure research (e.g., Rankin, 1996) suggested that users, mainly investors, are demanding more information than they are getting. Further evidence (e.g., Beattie and Pratt, 2002; Solomon et al., 2000; ICAEW 1997, 1999; Schrand and Elliott, 1998) noted investors demand for more information to help them assess a company risk profile and make informed decisions. This has created a reporting gap or information problem. This information problem, actually a form of information asymmetry, occurs when management holds information and withholds it from investors for certain reasons, including commercial sensitivity and uncertainty about measurements. It is a key issue in corporate disclosure that may disturb the functioning of the capital markets leading to their partial or complete breakdown (Akerlof, 1970). 
This emphasised the importance of narrative disclosure where additional information on company's performance, prospects, and risk and uncertainties are prepared. The regulator and accounting setters in the UK have long recognised the importance of the topic. The Companies Act 1985 requires companies for a 'description' of the principal risks and uncertainties that they face in a 'business review' section identified as part of the Directors' Report (Companies Act 1985, S.234). There has been long constructive discussion and debate over the Operating and Financial Review (OFR) which was first launched by ASB in 1993 (ASB, 1993), with a revised statement being issued in 2003 (ASB, 2003), recommending UK listed companies to discuss principal risks and uncertainties. The issuance of the statement was an important shift emphasising the importance of narrative disclosure. The government concluded that it was not practical to regulate the OFR by law, partly because of the question of whether Directors could be sued over poor judgments in risk analysis published in the OFR (the question of safe harbour protection), and in 2006 it was left to the ASB to issue a Reporting Statement (replacing Reporting Standard RS 1) recommending that "the OFR should include a description of the principal risks and uncertainties facing the entity together with a commentary on the directors' approach to them" (ASB, 2006, para 52). The requirements for a business review remain. Risk disclosure is also influenced by the standard setters' requirements through the issuance of accounting standards (e.g., FRS 13, IAS 32, IAS 39, IFRS 7 and IFRS 8) underpinning the reporting of risk.

The growing literature on Corporate Governance (CG) provides further evidence that the information needs of users have been recognised by regulators and accounting professions. The CG debate began with the publication in 1992 of Cadbury Report which recognised the needs of users for some explanation of the factors likely to influence a company future progress. Cadbury Report was followed by the publication of a series of statements and guidelines (e.g., Combined Code and Turnbull Report). Under the Combined Code (1998), companies' directors should state whether they complied with the code by conducting annual review of all controls and risk management system. The Turnbull Report issued in 1999 (Turnbull Report, 1999) underlined the importance of internal control and risk management and explicitly encouraged UK companies' directors to provide the users of corporate report with high quality and meaningful information related to key risks.

The information needs of users include those related to risk and uncertainties were also long noted and debated by accounting institutes worldwide. For example, in the UK, the Institute of Chartered Accountants in England and Wales (ICAEW) showed an early interest in the subject and issued several documents in order to help companies' directors to identify, manage and measure risk and further enhance their public disclosure by providing more relevant risk-related information on all types of risk that have a potential bearing upon corporate performance. The best examples are Financial Reporting of Risk: Proposals for a Statement of Business Risk; issued in 1997; and No surprises: the case for better risk reporting issued in 1999.

\subsection{Corporate disclosure: motivations and benefits}

In research on corporate disclosure, the issue of understanding the motivations for disclosure has attracted considerable attention. Researchers on accounting disclosure have been applying a number of theoretical frameworks to explain what motivates managers to disclose more information than it is necessitated by regulation. However, 
there is no single theory available to explain disclosure phenomenon completely, and researchers to date tend to select whichever theory articulates best with their hypothesis (Linsley and Shrives, 2000). Examples of theories include agency theory, signalling theory, stakeholders' theory, capital need theory, political cost theory and benefit-cost theory. Linsley and Shrives (2000) suggest that some of these theories could be relevant for discussion of the motivation of risk disclosure. Companies may disclose information in order to meet investors demand for information, thus reduce their interference by publishing additional information. Information asymmetries can be a serious problem that if occurs it may disturb the functioning of the capital markets leading even to their partial or complete breakdown (Akerlof, 1970). The evidence (e.g., Lang and Lundholm, 1996; Botosan, 1997; Hail, 2002) suggests that additional disclosure benefits companies as it increases transparency and reduces information asymmetries, thus reducing cost of capital. A reduction in information asymmetries makes investors more confident to trade at a fair price, leading to higher stock liquidity (Diamond and Verrecchia, 1991; Welker, 1995). Companies may benefit from making additional disclosure so as to send signals to the market that there is no need for new requirements (signalling theory) and/or reduce the chance of more detailed and perhaps more costly requirements being introduced by accounting regulators (political cost theory).

The benefits of improved risk reporting should not be seen as being purely limited to individual investors or to the managers who gain investors confidence by such reporting. There are potential economic benefits to the wider community in terms of better risk-based resource allocation, with increased long-term capital formation as a result. The need to report on risks and risk management can also be expected to lead to improved internal information being collected on the risks that the enterprise faces, as well as the need to demonstrate that the risks identified are being managed, as shareholders hold directors to account for their risk management.

However, companies' directors are sometimes reluctant to disclose additional disclosure because competitors may make strategic use of information disclosed to their advantage (Edwards and Smith, 1996; Linsley and Shrives, 2005; Tsakumis et al., 2006). This may lead to the imposition of a proprietary cost, hence putting a company at a competitive disadvantage and affecting the company negatively. Thus, a firm has to trade off the positive and negative effects of voluntary disclosure.

In addition, it is essential to consider the differing demands of investors and regulators in different countries in examining the levels of risk reporting found in annual accounts. Culture, recent history and education can all affect market demand for such information. However, even without such demands, the demands of regulators will create differences in levels of risk reporting between different jurisdictions and between the firms listed on different stock exchanges. This gives rise to an expectation that companies listed in more than one country will on average disclose more about their risks than other companies, as they strive to meet the demands of their most exacting regulator, in addition to any particular requirements of the other regulators they must satisfy. For this reason, the present study examines the effects of US-listings on the level of risk reporting by UK companies. US-listed companies face additional risk reporting requirements under regulations such as Securities and Exchange Commission (SEC) Regulation S-K \$229.503, requiring identification of key business factors in prospectuses (SEC, 2008c) and the requirement to repeat this information in the corporate annual report in (SEC, 2008a, Item 1A) UK firms with a US listing are required to reconcile financial statements to US accounting standards and submit this via form $20-\mathrm{F}$ to the 
SEC. The instructions for Form $20-\mathrm{F}$ require that "the document shall prominently disclose risk factors that are specific to the company or its industry" (SEC, 2008b, p.11, Item 3D). Moreover, they are required to report on internal controls under the SarbanesOxley Act (2002), Sections 302 and 404, while section 401 requires enhanced disclosures on risks involved in off-balance sheet special purpose vehicles.

\subsection{Previous studies}

Recently there has been substantial growth in the research attention being devoted to risk disclosure in companies' annual reports. Although corporate financial and environmental disclosures have been developing for a number of decades, recent evidence (e.g., Stanton and Stanton, 2002; Beattie, 2005) found little research related to annual report risk disclosure. This increase in attention for risk disclosure can be demonstrated by the increased focus being applied by governments and accounting regulators, and accounting institutions, signifying its importance. A number of studies examining risk disclosure started to evolve (e.g., Abraham and Cox, 2007; Linsley and Shrives, 2006; Woods and Reber, 2003). These studies investigated different issues, covered different data sets; and applied different studies samples. For example, Beretta and Bozzolan (2004) proposed a framework of risk communication and applied it on a sample of non-financial companies listed in the ordinary market on the Italian Stock Exchange. Woods and Reber (2003) carried out a pilot study on twelve companies to compare disclosure between UK and Germany.

The present study fills a gap in the literature by providing a longitudinal study of the type and nature of corporate risk information disclosed in the annual report. This study distinguishes itself from previous studies as it seeks to determine whether companies' annual report risk disclosure has enhanced over the years under study in response to recent regulatory changes and developments.

\section{Hypotheses development}

Given the debate on risk disclosure, the main impetus of this study was to determine whether risk disclosure in annual reports of UK firms has enhanced over the period under study in response to regulatory development and changes that occurred lately. Any increase in risk disclosure would be seen as evidence confirm the effectiveness of recent efforts at CG reforms (Solomon et al., 2000) and recommendations made by accounting institutes for enhancing risk disclosure and reducing information asymmetry. Patten (1992) and Deegan et al. (2000) provide examples of studies where the volume of environmental disclosure was shown to respond to the increased exposure to criticisms experienced after a particular event. Thus we would expect risk disclosure to have increased over the years, and operationalised this expectation in the following first research Hypothesis:

$H_{1}$ : The level of risk disclosure has significantly increased over time in response to recent regulatory development and other pressure.

Prior research suggests that several factors (e.g., financial factors, non-financial factors, and social responsibility factors) may determine firm's disclosure policy. In this research 
we investigated the effect of size, leverage, industry and US dual listing. These are the most commonly used independent variables in accounting disclosure research.

Prior research (e.g., Hossain et al., 1994; Meek et al., 1995; Raffournier, 1995; Depoers, 2000) suggests there may be a positive relation between disclosure and size. The proportion of outside capital tends to be higher for larger companies and agency theory suggests agency costs (monitoring costs) increase with the amount of outside capital (Jensen and Meckling, 1976). Thus larger firms may have greater incentives to disclose more information in order to reduce agency costs, hence reduce information asymmetries between managers and shareholders. The demand for information by analysts could be greater on larger firms (Hossain et al., 1994). These argument leads to the second hypothesis:

\section{$\mathrm{H}_{2}$ : The extent of risk disclosure is positively related to firm size.}

Industry can also be an important factor in explaining corporate disclosure (Beretta and Bozzolan, 2004). This variable may have the potential to influence the amount and nature of information disclosed by companies. The influence of industry variable has been proposed by political cost theory and signalling theory (Inchausti, 1997). Companies in certain industries (e.g., sensitive industries) will attract the attention of public and governmental bodies concerns (Adams et al., 1998). Disclosure may, therefore, serve as a mechanism to ensure that public concerns are answered. Beretta and Bozzolan (2004) suggest that company risk profile is deeply influenced by the technological and market constraints exerted by the competitive industrial environment on the business models. Cooke (1992) found that Japanese manufacturing companies disclose more information than non-manufacturing firms. The above arguments lead us to the second hypothesis:

$H_{3}$ : The extent of risk disclosure is higher for some firms (heavy industrial firms) than for other firms.

Listing factor have been proposed by many studies in accounting disclosure as an important factor in explaining disclosure practices. Listing in foreign stock exchanges gives firms an opportunity to raise capital (perhaps at a lower cost) in the foreign capital markets. Firms may want to increase their disclosure, perhaps in order to create or maintain strong demand for their securities. Another reason that has been put forward for additional disclosure is that the foreign stock markets may require extra disclosure. This lead to the fourth hypothesis:

$H_{4}$ : The extent of risk disclosure is higher for UK firms with a US-dual listing than for those without a US-dual listing.

It has been proposed that capital structure of a firm is related to agency cost (Jensen and Meckling, 1976). Agency costs are higher in highly leveraged firms (i.e., more debt in the capital structures) because a large proportion of debt allows greater potential wealth transfers from debtholders to shareholders (Jensen and Meckling, 1976). Thus, agency theory predicts that corporate disclosure is expected to increase with leverage. However, the empirical evidence on this hypothesis is contradictory. For example, Oliveira et al., (2006), Meek et al. (1995) and Raffournier (1995) found no significant relation with disclosure whilst others (e.g., Malone et al., 1993) found a positive association. The above arguments lead to the following fifth hypothesis.

$H_{5}$ : The extent of risk disclosure is positively related to leverage. 


\section{Sample selection and research methods}

The analysis is based on a sample extracted from UK listed companies and covers three different time periods (1998, 2001 and 2004). Based on the selection criteria, a sample comprising annual reports of 52 non-financial companies listed in the FTSE-100 index was found. Thus, in total 156 annual reports were sought, collected and analysed. A three-year interval was chosen to give greater time coverage for the analysis, hence allowing more in-depth examination of the trends. Companies span a wide range of businesses. The 52 companies were classified into eight industry categories, based on London Stock Exchange (LSE) classification: namely, Resources (RE), Basic Industries (BI), General Industries (GI), Non-Cyclical Consumer Goods (NCCG), Cyclical Services (CS), Non Cyclical Services (NCS), Utilities (UT) and Information Technology (IT). To make comparison easier, Information technology is consolidated with CS because it has only one constituent company, Sage. Thus, this reduces industry categories to seven categories. Table 1 displays the sampled companies classified according to industry sectors.

The sample size was limited by the number of available large listed companies in the UK. Nevertheless, sufficient data was obtained from these companies' annual reports to allow conclusions to be drawn on the questions raised in this paper, as shown below. The sample size is comparable to other studies on corporate disclosure, such as Hail (2002), Oliveira et al. (2006) and Branco and Rodrigues (2008).

Table 1 Sample selection

\begin{tabular}{lc}
\hline Categories & Number of observant \\
\hline Resources (RE) & 4 \\
Basic Industries (BI) & 5 \\
General Industries (GI) & 2 \\
Non-cyclical consumer goods (NCCG) & 9 \\
Cyclical services and information technology (CS\&IT) & 22 \\
Non-cyclical service (NCS) & 4 \\
Utilities (UT) & 6 \\
Total & 52 \\
\hline
\end{tabular}

Content analysis (e.g., Neu et al., 1998; Milne and Adler, 1999; Campbell, 2004; Linsley and Shrives, 2006) is used to determine the themes of risk disclosure. Content analysis can be used to note either the presence or the absence of a theme in written broadcast or other verbal material. It is useful method as it allows for disclosure to be systematically classified and compared and also useful in comparing trends (Milne and Adler, 1999). In content analysis, different counting measures can be used which include 'word', 'sentence', 'page' and 'number of lines'. In this study, 'sentence' was used as it is more likely to provide data which are complete, reliable and meaningful (Milne and Adler, 1999).

Content analysis requires the researcher to design and implement a coding scheme involving a number of stages (e.g., Weber, 1985; Wolfe, 1991). In the implementation of this approach, the researcher is required to determine the following: the research question (e.g., measuring risk disclosure); the codable document (e.g., annual report); the coding unit (e.g., sentence), disclosure categories (e.g., environmental risk, operational risk; 
strategic risk); and the coding mode (e.g., manual). In addition, the researcher needs to assess the reliability of coding. Last of all, the coded information is subjected to interpretation.

Following previous studies (e.g., Linsley and Shrives, 2006; Woods and Reber, 2003), an analysis instrument (checklist) was designed and utilised so disclosure can be classified according to four different quality variables to allow the examination of content and style of information disclosed. These variables include risk disclosure categories (Environmental risk, Operational risk and Strategic risk) (see appendix A); the nature of evidence (i.e., quantitative and qualitative); the type of news (good, bad, neutral) and news time-frame (past, future, non-time). Based on the coding scheme, each company's annual reports (excluding accounts and the notes to accounts) for the fiscal years 1998, 2001, and 2004 were examined and risk disclosure texts (containing risk relevant information that facilitates the reader to be better informed about past and potential threats or opportunities arising from external or internal variables, and about risk management (e.g., Linsley and Shrives, 2006) were detected and analysed manually. The texts were measured by the number of sentences and matched to risk disclosure categories. A set of decision rules were applied and a pilot sample of reports was analysed and a number of procedures were followed to ensure the reliability and validity of disclosure measure. Table 2 shows an analysis of risk disclosure sentence characteristics.

Table 2 Analysing risk disclosure

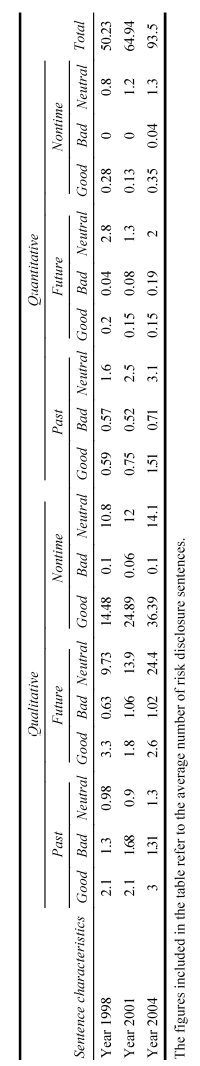




\section{Results}

\subsection{Overall trends in risk disclosure}

Recently, there has been an increase in users' demands for corporate information. The literature shows that companies were put under pressure to make even greater disclosure of corporate information especially those related to risks and uncertainties. This is the background against which the results of this study should be interpreted. This study sets out to examine how companies responded to the growing pressure and demands. Table 3 displays the results of content analysis. The table shows that all companies in the sample disclosed risk-relevant information. The results displayed in the table show that the average (mean) number of risk disclosure sentences has steadily increased across the period under study, rising from 50.23 sentences in 1998 to 64.94 in 2001 and 93.5 in 2004. The table also shows that the average disclosure attributed to each category (i.e., environmental risk, operational risk and strategic risk) has also increased. This provides evidence that there is an upward trend in the average amount of risk disclosure being published by the sample of companies over the period from 1998 to 2004. Average disclosure, regardless of form (quantitative and qualitative), time-scale (past, future, non-time) and type of news (good, bad or neutral) all increased overall. However, quantitative disclosure decreased slightly between 1998 and 2001 and bad news disclosure slightly decreased between 2001 and 2004. The results show that operational risk disclosure dominates, reflecting its growing importance. Items under this category such as risk management policies and internal control, liquidity and cash flow risk, environment and health and safety risk and compliance; received higher ranks than items covered under the other two categories.

Table 3 The overall trend in risk reporting

\begin{tabular}{llcccc}
\hline \multirow{2}{*}{$\begin{array}{l}\text { Disclosure } \\
\text { characteristics }\end{array}$} & Code & Year 1998 & Year 2001 & Year 2004 \\
\cline { 4 - 6 } Quantity & Total risk disclosure & $\begin{array}{c}\text { Average } \\
\text { disclosure }\end{array}$ & $\begin{array}{c}\text { Average } \\
\text { disclosure }\end{array}$ & $\begin{array}{c}\text { Average } \\
\text { disclosure }\end{array}$ \\
\hline Content & Environmental risk disclosure & 52 & 7.64 & 12.43 & 93.5 \\
& Operational risk disclosure & 52 & 34.12 & 41.50 & 60.64 \\
& Strategic risk disclosure & 52 & 8.47 & 11.01 & 13.58 \\
Form of & Qualitative disclosure & 52 & 43.40 & 58.36 & 84.10 \\
disclosure & Quantitative disclosure & 52 & 6.83 & 6.58 & 9.40 \\
Time-scale & Past news & 52 & 7.11 & 8.42 & 10.96 \\
& Non-time & 52 & 26.43 & 38.25 & 52.21 \\
& Future & 52 & 16.70 & 18.25 & 30.32 \\
Type of news & Good news & 52 & 20.97 & 29.84 & 43.98 \\
& Bad news & 52 & 2.63 & 3.39 & 3.37 \\
& Neutral news & 52 & 26.63 & 31.71 & 46.15 \\
\hline
\end{tabular}

The figures included in the table refer to the average number of risk disclosure sentences. 
Table 2 provides an in-depth and detailed analysis of risk disclosure sentence characteristics. The table exhibits a clear analysis of the form and type of the information disclosed.

The results show that companies reveal both qualitative and quantitative disclosure. However, qualitative disclosures dominate over quantitative disclosures. The companies also publish 'past', 'non-time', and 'future' disclosure with non-time disclosure found to be dominating. In terms of news type, it was noted that companies disclose little 'bad news' information in comparison to 'good' and 'neutral' news disclosures.

\subsection{Hypothesis testing}

To test hypothesis 1, A Wilcoxon signed rank test was conducted to evaluate whether the average level of risk disclosure in 2004 was higher than the average level in 2001 and in 1998. The results, displayed in Table 4, indicate that there are significant differences between years 1998-2001; 1998-2004 and 2001-2004. The $z$ value $=-4.538 ;-6.071$ and -5.711 , respectively, with a significant value of 0.000 each. A $t$-test for paired samples was also performed to determine if there was any significant difference between the mean level of risk disclosure in the different periods under examination. This is an additional test and is conducted to support the Wilcoxon signed-rank test. The results displayed in Table 5 also indicate that there are significant differences in the mean level of risk disclosure between the years, confirming the results of Wilcoxon signed-rank tests.

Table 4 Results of the Wilcoxon signed-rank test

\begin{tabular}{lccc}
\hline & $1998-2001$ & $1998-2004$ & $2001-2004$ \\
\hline$Z$ & -4.538 & -6.071 & -5.711 \\
Asymp. Sig (2-tailed) & 0.000 & 0.000 & 0.000 \\
\hline
\end{tabular}

Table 5 Results of the student $t$ test

\begin{tabular}{lccc}
\hline & $1998-2001$ & $1998-2004$ & $2001-2004$ \\
\hline$T$ & -5.404 & -7.941 & -6.088 \\
Sig (2-tailed) & 0.000 & 0.000 & 0.000 \\
\hline
\end{tabular}

To test the remaining hypotheses, Pearson correlation coefficients have been computed to test the association between risk disclosure scores and the independent continuous variables (i.e., size and leverage). Table 6 gives the descriptive statistics for disclosure scores and the independent continuous variables. Pearson correlation coefficients are displayed in Table 6 (last column). Figures in the table are related to the most recent year, year 2004.

The results indicate that there is no strong evidence that risk disclosure score is related to either size or leverage, contrary to the predictions of agency theory. Deloitte (2006) found that the quality of disclosure on markets and external environment did not vary by size of company. Other evidence (e.g., Aljifri, 2008) did not support a positive relationship between disclosure level and size. As with size variable, leverage was found to have insignificant association with the level of risk disclosure. Previous evidence 
(Aljifri, 2008; Oliveira et al., 2006; Meek et al., 1995; Malone et al., 1993) tested the association between disclosure level and leverage variable is contradictory.

Table 6 Descriptive statistics and Pearson correlation coefficients between risk disclosure and firm's variables (size and leverage)

\begin{tabular}{lccccc}
\hline & Min & Max & Mean & SD & Pearson correlation \\
\hline Risk disclosure score & 28.00 & 275.00 & 93.50 & 54.12 & N/A \\
Size & 6.57 & 11.98 & 8.46 & 1.23 & 0.084 \\
Sig. (2-tailed) & & & & & 0.554 \\
Leverage & 1.50 & 527.18 & 131.15 & 106.99 & 0.066 \\
Sig. (2-tailed) & & & & & 0.660 \\
\hline
\end{tabular}

Total disclosure is the firm's total number of risk disclosure sentences on three categories: namely, environmental risk, operational risk, and strategic risk disclosures. Size is the log of turnover at the fiscal year end of 2004. Leverage is the ratio of total debt to total equity.

In an attempt to examine the relationship between the type of industry variable and risk disclosure level, the sample companies were initially categorised into seven industrial groups as explained above (and displayed in Table 1). Based on this classification, a One-way ANOVA test was carried out on most recent year results, year 2004. Table 7 presents the results which show significant differences between industries.

Table 7 Testing the differences in average (mean) risk disclosure between industries for the year 2004 (ANOVA test)

\begin{tabular}{lcccccccccc}
\hline & $R E$ & $B I$ & NCCG & CS\&IT & NCS & UT & GI & \multicolumn{2}{c}{ ANOVA } \\
\cline { 2 - 10 } & Mean & Mean & Mean & Mean & Mean & Mean & Mean & & \\
Disc. & Disc. & Disc. & Disc. & Disc. & Disc. & Disc. & F & Sig. \\
\hline $\begin{array}{l}\text { Andustry } \\
\text { disclosure risk score } \\
\text { (year 2004) }\end{array}$ & 121 & 177 & 112 & 60 & 92 & 97 & 101 & 5.091 & 0.000 \\
\hline
\end{tabular}

RE: Resources, BI: Basic industries, NCCG: Non-cyclical consumer goods,

CS\&IT: Cyclical services and information technology, NCS: Non-cyclical services,

UT: Utilities, GI: General industries.

Following this categorisation, the companies were also further divided into dichotomous groups based on whether they are industrial or non-industrial companies. This classification is in line with some previous studies (Adams et al., 1998; Raffournier, 1995). The dichotomous approach was also followed to classify companies in the sample according to whether or not companies have a US dual listing in addition to their UK listing. Having developed this classification, two statistical tests were performed, a student's $t$ test and a Mann-Whitney $U$ test. The results of the Student's $t$ test presented in Table 8 (panel A) suggest that there is a significant difference in risk disclosure score $(p<0.001)$ between the two groups of industries. As hypothesized, firms belonging to heavy industrial sectors are disclosing more information than those whose belong to non-industrial sectors. The Mann-Whitey $U$ test yields a $Z$ statistic $-4.027(p<0.001)$, which supports the results of the student $t$ test. 
These two tests were also carried out on the data (results are displayed in Table 8, panel B) to test for the differences in mean risk disclosure scores between US dual listing and non US dual listing. The Student's $t$ test results (panel B) show that there is a statistically significant difference $(p<0.001)$ in risk disclosure scores between the two groups. It appears that UK firms with a US dual listing have a greater propensity to disclose information than other companies without a US dual listing. The Mann-Whitney $U$ test yields a $Z$ statistic of $-0.3 .89(p<0.001)$, which again supports the results of student $t$ test.

Table 8 Descriptive statistics and tests for risk disclosure score and firm's categorical variables (industry and US dual listing variables)

\begin{tabular}{|c|c|c|c|c|}
\hline \multicolumn{5}{|l|}{ Panel (A) } \\
\hline & Industrial (26) & Non-industrial (26) & Student's t test & $\begin{array}{c}2-\text { tailed } \\
\text { probability }\end{array}$ \\
\hline Mean disclosure score & 121.80 & 65.19 & -4.398 & 0.000 \\
\hline Std. Deviation & 58.97 & 28.82 & & \\
\hline \multicolumn{5}{|c|}{ Mann-Whitney $Z=-4.027 ; 2-$ tailed probability 0.000} \\
\hline \multicolumn{5}{|l|}{ Panel (B) } \\
\hline & $\begin{array}{c}\text { US dual listing } \\
\text { (28) }\end{array}$ & $\begin{array}{c}\text { Non US dual listing } \\
\text { (24) }\end{array}$ & Student's t test & $\begin{array}{c}2-\text { tailed } \\
\text { probability }\end{array}$ \\
\hline Mean disclosure score & 124.08 & 67.28 & -4.193 & 0.000 \\
\hline Std. Deviation & 60.41 & 29.65 & & \\
\hline \multicolumn{5}{|c|}{ Mann-Whitney $Z=-3.89 ; 2-$ tailed probability 0.000} \\
\hline
\end{tabular}

\section{Discussion of disclosure results}

In the basis of the comparison made over the period from 1998 to 2004, we observed what was expected that there is a general increase in the level of information disclosed on risk disclosure. Yet still relatively little detailed disclosure is provided. Much of the disclosure appears to be linked to general risk causes where companies report that they are expose to/or they may face various types of risks which may affect their operations (qualitative/future/neutral disclosure). Much of the disclosure was also on qualitative/non-time/neutral and qualitative/non-time/good news disclosure. These disclosures comprise those disclosures linked to internal control systems, risk management policies, corporate social responsibility risk (include health and safety and environment risk) and others. Overall, we have seen more reporting on risk factors, general statement of risk management policy, and control system than detailed reporting on what would be the impact of such risk. Some of the disclosure related to internal control is mandated under Turnbull committee, which requires a description of the system in place to identify, evaluate and manage risk. A general feature appears to be the desire of companies' directors to provide bad news as well as good and neutral news although the level of bad news disclosure remains low. Another feature appears in the willingness of directors to disclose information related to the future. Evidence (e.g., Cabedo and Tirado, 2004; Solomon et al., 2000, Linsley and shrives, 2000) 
suggests that investors demand more information related to the future, as it improves their decision making process. However, this demand is unlikely to be satisfied by present practice, as most of the disclosures related to the future are neutral news and qualitative. These disclosures are often bland and commonplace and lack the completeness that would be ensured by the inclusion of good and bad news and the concreteness of quantitative data. The results show little information linked to 'future quantitative disclosure' and 'future bad news disclosure'. Evidence suggests (e.g., Skinner, 1994) that company directors withhold negative information (especially those related to the future) when they feel this is necessary to avoid excessive legal costs or reputation concerns. Nonetheless, understandably there are difficulties associated with forecasting the future and quantifying risk due for example to data availability and subjectivity in measurement. For example, one company writes

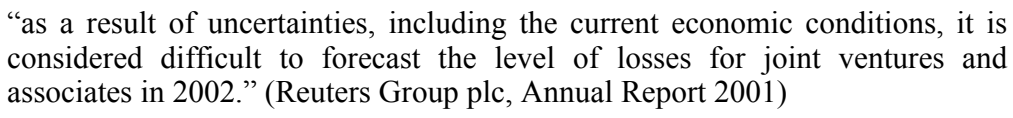

"as a result of uncertainties, including the current economic conditions, it is considered difficult to forecast the level of losses for joint ventures and associates in 2002.” (Reuters Group plc, Annual Report 2001)

This is an example of future bad news disclosure, as it deals exclusively with losses but it lacks any quantitative information. Other typical risk disclosure examples are presented in Appendix B. There are also some circumstances where directors are reluctant to release forward-looking risk information without safe harbour protection and when disclosure are deemed too commercially sensitive (Linsley and Shrives, 2005). The proposed 'safe harbour' provisions in the companies act 2006 may encourage companies to give greater details moving forward (ASB, 2007).

The results show that listing and industry variables are significantly related to the level of risk disclosure. This was expected as there are additional disclosure requirements for companies quoted on US stock markets. For the industry variable, industrial companies were found to disclose more than other companies. This may be due to certain industries being subject to more complex regulations than others or the result of a herd instinct or bandwagon effect where companies increase their level of disclosure in order to avoid the appearance of failing to meet the standards set by other similar companies. The results suggest that the regulation effect far outweighs the market effect. However, prior evidence suggests that regulation influences the quantity of disclosure but cannot ensure the quality of information disclosed.

\section{Conclusion}

This study was carried out to examine how companies responded to recent regulatory developments and other pressures on corporate reporting. The study further examined the relationship between risk disclosure in annual report and four company variables include company size, industry type, US dual listing and leverage.

Although disclosure level, reflecting the effect of regulation, was found to be increased over the years, the analysis indicates that there are so many bland statements being disclosed by companies. Thus, the nature of information disclosed is of questionable quality and hence of questionable relevance to investors. Investors may be concerned that risk disclosure may not fully enable them to assess companies risk profiles. Accordingly, the usefulness of the risk information disclosed by companies remains a question for future research. This is of considerable concern in the present 
economic and financial environment. The scandals and failings in corporate management in recent years do not need to be addressed by bland statements and reassurances. Rather there is a need for full, detailed and unbiased statements of the risks that companies face, the degree of risk that managers are prepared to tolerate and the measures taken to keep risks within the tolerance level stated.

The study has a number of limitations. Our sample was extracted from the FTSE 100 companies so the sample choice should be considered when the conclusion is drawn. A further research study could extend the sample to include medium-sized and smaller companies. The second limitation is that our analysis is restricted to disclosure available on the annual report only. Previous evidence suggests that managers disclose good news forecasts information and bad news information (e.g., Skinner, 1994) promptly to avoid litigation costs. It is acknowledged that companies communicate with stakeholders through other channels, such as interim reports, preliminary announcements, and the internet. Future research could examine these other forms of information disclosure.

Finally, in view of the potential role of risk disclosure in reducing information asymmetries and thereby increasing investors' confidence, it would be valuable to conduct further research to establish whether there is any negative correlation between risk disclosure and cost of capital reflecting this improvement in investor sentiment.

\section{Acknowledgments}

We would like to express our gratitude to those who have assisted us in the development of this paper and provided help and guidance in the research leading to its development. In particular, we would like to thank Prof. Simon Gao and Dr. Les Short from Napier University Business School, Dr. Michael Busler of Rowan University, New Jersey and other participants at the World Association for Sustainable Development Conference at the University of Sussex in 2008, and the editors and anonymous referees for their helpful comments in relation to an earlier draft of this paper.

\section{References}

Abraham, S. and Cox, P. (2007) 'Analysing the determinants of narrative risk information in UK FTSE 100 annual reports', British Accounting Review, Vol. 39, pp.227-248.

Adams, C., Hill, W.Y. and Roberts, C.B. (1998) 'Corporate social reporting practices in Western Europe: legitimating corporate behaviour’, British Accounting Review, Vol. 30, pp.1-21.

AICPA (1987) Report of the Task Force on Risk and Uncertainties, American Institute of Certified Public Accountants, New York, NY.

Akerlof, G. (1970) 'The market for 'lemons': quality uncertainty and the market mechanism', Quarterly Journal of Economics, Vol. 84, No. 3, pp.488-500.

Aljifri, K. (2008) 'Annual report disclosure in a developing country: The case of UAE', Advances in Accounting, Incorporating Advances in International Accounting, Vol. 24, pp.93-100.

ASB (1993) Reporting Statement: Operating and Financial Review, Accounting Standards Board, London.

ASB (2003) Operating and Financial Review (Revised), Accounting Standards Board, London.

ASB (2006) Reporting Statement: Operating and Financial Review (Revised), Accounting Standards Board, London, http://www.frc.org.uk/images/uploaded/documents/Reporting\%20 Statements\%20OFR\%20web.pdf 
ASB (2007) A Review of Narrative Reporting by UK Listed Companies in 2006, Accounting Standards Board, London.

Beattie, V. (2005) 'Moving the financial accounting research front forward: the UK contributon', British Accounting Review, Vol. 37, No. 1, pp.85-114.

Beattie, V. and Pratt, K. (2002) Voluntary Annual Report Disclosures: What Users Want, Institute of Chartered Accountants of Scotland, Edinburgh.

Beretta, S. and Bozzolan, S. (2004) 'A framework for the analysis of firm risk communication', International Journal of Accounting, Vol. 39, pp.265-288.

Botosan, C.A. (1997) 'Disclosure level and the cost of equity capital', The Accounting Review, Vol. 72, No. 3, pp.323-349.

Branco, M.S. and Rodrigues, L.L. (2008) 'Factors influencing social responsibility disclosure by Portuguese companies', Journal of Business Ethics, Vol. 83, No. 4, pp.685-701.

Cabedo, J.D. and Tirado, J.M. (2004) 'The disclosure of risk in financial statements', Accounting Forum, Vol. 28, pp.181-200.

Cadbury Report (1992) Report of the Committee on the Financial Aspects of Corporate Governance, London.

Campbell, D. (2004) 'A longitudinal and cross-sectional analysis of environmental disclosure in UK companies - a research note', British Accounting Review, Vol. 36, pp.107-117.

Cavendish Asset Management (2002) Survey of UK investors by Cavendish Asset Management, Cavendish Asset Management, London.

Combined Code (1998) Combined Code, The London Stock Exchange Limited, London.

Cooke, T.E. (1992) 'The impact of size, stock market listing and industry type in disclosure in the annual reports of Japanese listed corporations', Accounting and Business Research, Vol. 22, No. 87, pp.229-237.

Deegan, C., Rankin, M. and Voght, P. (2000) 'Firms' disclosure reactions to major social incidents: Australian evidence', Accounting Forum, Vol. 24, No. 1, pp.101-130.

Deloitte (2006) Write to Reason: Surveying OFRs and Narrative Reporting in the Annual Reports, October, Deloitte, London.

Depoers, F. (2000) 'A cost - benefit study of voluntary disclosure: some empirical evidence from French listed companies', European Accounting Review, Vol. 9, No. 2, pp.245-263.

Diamond, D. and Verrecchia, R. (1991) 'Disclosure, liquidity and the cost of equity capital', Journal of Finance, Vol. 46, No. 4, pp.1325-1360.

Edwards, P. and Smith, R.A. (1996) 'Competitive disadvantage and voluntary disclosures: the case of segmental reporting', British Accounting Review, Vol. 28, No. 2, pp.155-172.

Hail, L. (2002) 'The impact of voluntary corporate disclosure on the ex-ante cost of capital for Swiss firms', European Accounting Review, Vol. 11, No. 4, pp.741-773.

Hossain, M., Tan, L.M. and Adams, M. (1994) 'Voluntary disclosure in an emerging capital market: some empirical evidence from companies listed on the Kuala Lampur Stock Exchange', International Journal of Accounting, Vol. 29, No. 4, pp.334-351.

ICAEW (1997) Financial Reporting of Risk: Proposals for a Statement of Business Risk, Institute of Chartered Accountants in England and Wales, London.

ICAEW (1999) No Surprise: The Case for Better Risk Reporting, Institute of Chartered Accountants in England and Wales, London.

Inchausti, B.G. (1997) 'The influence of company characteristics and accounting regulation on information disclosed by Spanish firms', The European Accounting Review, Vol. 6, No. 1, pp.45-68.

Jensen, M.C. and Meckling, W.H. (1976) 'Theory of the firm: managerial behavior, agency cost and ownership structure', Journal of Financial Economics, Vol. 3, No. 1, pp.305-360.

Kaplan, R.S. and Norton, D.P. (1996) Balanced Scorecard: Translating Strategy into Action, Harvard Business School Press, Boston. 
Lang, M. and Lundholm, R. (1996) 'Corporate disclosure policy and account behaviour', The Accounting Review, Vol. 7, No. 4, pp.467-492.

Linsley, P. and Shrives, P. (2000) 'Risk management and reporting risk in the UK', Journal of Risk, Vol. 3, No. 1, pp.115-129.

Linsley, P. and Shrives, P. (2005) 'Transparency and disclosure of risk information in the banking sector', Journal of Financial Regulation and Compliance, Vol. 13, No. 3, pp.205-214.

Linsley, P. and Shrives, P. (2006) 'Risk reporting: a study of risk disclosures in the annual reports of UK companies', British Accounting Review, Vol. 38, pp.387-404.

Malone, D., Fries, C. and Jones, T. (1993) 'An empirical investigation of the extent of corporate financial disclosure in the oil and gas industry', Journal of Accounting, Auditing and Finance, Vol. 8, pp.249-273.

Meek, G.K., Roberts, C.B. and Gray, S.J. (1995) 'Factors influencing voluntary annual reports disclosures by US, UK and Continental European multinational corporations', Journal of International Business Studies, Vol. 36, No. 3, pp.555-572.

Milne, M.J. and Adler, R.W. (1999) 'Exploring the reliability of social and environmental disclosure content analysis', Accounting, Auditing, and Accountability Journal, Vol. 12, No. 2 , pp.237-256.

Neu, D., Warsame, H. and Pedwell, K. (1998) 'Managing public impressions: environmental disclosures in annual reports', Accounting, Organizations and Society, Vol. 23, pp.265-282.

Oliveira, L., Rodrigues, L.L. and Craig, R. (2006) 'Firm-specific determinants of intangibles reporting: evidence from the Portuguese stock market', Journal of Human Resource Costing and Accounting, Vol. 10, No. 1, pp.11-33.

Patten, D.M. (1992) 'Intra-industry environmental disclosure in response to the Alaskan oil spill: a note on legitimacy theory', Accounting, Auditing, Organizations and Society, Vol. 17, No. 5, pp.471-475.

Raffournier, B. (1995) 'The determinants of voluntary disclosure by Swiss listed companies', European Accounting Review, Vol. 4, No. 2, pp.261-282.

Rankin, M. (1996) Corporate Reporting - The Green Gap, The Environmental Accounting Task Force of the Institute of Chartered Accountants in Australia, Sydney.

Sarbanes-Oxley Act (2002) Sarbanes-Oxley Act of 2002, H.R. 3763, http://thomas.loc.gov/cgi-bin/ query/D?c107:6:/temp/ c107GSOKtu

Schrand, C.M. and Elliott, J. (1998) 'Risk and financial reporting, a summary of the discussion at the 1997 AAA/ FASB conference', Accounting Horizons, Vol. 12, No. 3, pp.271-283.

SEC (2008a) Form 10-K: Annual Report pursuant to Section 13 or 15(D) of the Securities Exchange Act of 1934: General Instructions, http://www.sec.gov/about/forms/form10-k.pdf

SEC (2008b) Form 20-F, http://www.sec.gov/about/forms/form20-f.pdf

SEC (2008c) Standard Instructions for Filing Forms under Securities Act of 1933, Securities Exchange Act of 1934 and Energy Policy and Conservation Act Of 1975 - Regulation S-K, http://ecfr.gpoaccess.gov/cgi/t/text/text-idx?c=ecfr\&sid=20c66c74f60c4bb8392bcf9ad6fccea3 $\&$ rgn $=$ div5 \& view $=$ text\&node $=17: 2 \cdot 0 \cdot 1 \cdot 1.11 \&$ idno $=17$

Skinner, D. (1994) 'Why firms voluntarily disclose bad news', Journal of Accounting Research, Vol. 32, No. 1, pp.245-250.

Solomon, J.F., Solomon, A., Norton, S.D. and Josef, N.L. (2000) 'A conceptual framework for corporate risk disclosure emerging from the agenda for corporate governance reforms', British Accounting Review, Vol. 32, No. 4, pp.447-478.

Stanton, P. and Stanton, J. (2002) 'Corporate annual reports: research perspectives used', Accounting, Auditing, and Accountability Journal, Vol. 15, No. 4, pp.478-500.

Tsakumis, G.T., Doupnik, T.S. and Seese, L.P. (2006) 'Competitive harm and geographic area disclosure under SFAS 131', Journal of International Accounting, Auditing and Taxation, Vol. 15, No. 1, pp.32-47. 
Turnbull Report (1999) Internal Control: Guidance for Directors on the Combined Code, ICAEW, London.

Weber, R.P. (1985) Basic Content Analysis. Qualitative Applications in the Social Sciences, Sage, Beverly Hills, CA.

Welker, M. (1995) 'Disclosure policy, information asymmetry, and liquidity in equity markets', Contemporary Accounting Research, Vol. 11, No. 2, pp.801-827.

Wolfe, R. (1991) 'The use of content analysis to assess corporate social responsibility', Research in Corporate Social Performance and Policy, Vol. 12, pp.281-307.

Woods, M. and Reber, B. (2003) A Comparison of UK and German Reporting Practice in Respect of Disclosure Post GAS 5, Unpublished Conference Paper, 6th Financial Reporting and Business Communication Conference, Cardiff Business School, Cardiff.

\section{Appendix A}

\section{Risk disclosure categories}

\section{A.1 Environmental risk}

Environmental risk arises from factors essentially beyond the organisation's control and comprises disclosure relating to:

- economic risk (e.g., interest rate, currency risk, price and commodity, inflation, taxation, credit risk)

- political risk

- social risk

- regulation and legislation

- industry sources (e.g., competition, potential entrants, suppliers, substitutes, strategic partners, customers (e.g., changes in demand, changes in clients requirements and customers preferences))

- climate and catastrophic.

\section{A.2 Operational risk}

Operational risk is the probability of losses arising from the essential operation side of the firm.

Operational risk covers such issues as:

- internal control and risk management policies

- infrastructure risk

- liquidity and cash flow

- project failure

- product failure

- operational disruption 
- $\quad$ operational problem

- $\quad$ employment practices and workplace safety (H\&S)

- environment risk (risks arising from the impact of companies' operations on the natural environment)

- compliance and reputation

- legal risk.

\section{A.3 Strategic risk}

Strategic risks arise from operating in a particular industry and are associated with the company's future business plans and strategies. Strategic risks encompass:

- $\quad$ research and development

- $\quad$ product market

- intellectual property right

- $\quad$ acquisitions, alliances, joint ventures

- management of growth

- derivatives

- investment

- technology.

\section{Appendix B: Typical examples of risk disclosure}

\begin{tabular}{|c|c|c|}
\hline Risk disclosure example & Risk category & Sentence characteristics \\
\hline $\begin{array}{l}\text { Wolseley has its principal operations in North } \\
\text { America and Europe and therefore subject to } \\
\text { specific risks of conducting business in these } \\
\text { regions (Wolseley plc, Annual Report 2004) }\end{array}$ & Strategic risk & $\begin{array}{l}\text { Non- } \\
\text { time/qualitative/neutral }\end{array}$ \\
\hline $\begin{array}{l}\text { Hedging operations are subject to internal control } \\
\text { including review by an internal audit function } \\
\text { (Antogfasta, Annual Report 2004) }\end{array}$ & Operational risk & Non-time/qualitative/good \\
\hline $\begin{array}{l}\text { Our lost time injury frequency improved by } 15 \% \\
\text { in } 2004 \text {, reducing to } 0.6 \text { injuries per million man } \\
\text { hours worked (BG Group, Annual Report 2004) }\end{array}$ & Operational risk & Past/quantitative/good \\
\hline $\begin{array}{l}\text { Management does not anticipate that the dispute } \\
\text { with certain insurers over their declination of } \\
\text { coverage of macrotextured product liability claims } \\
\text { will be resolved during } 2005 \text {. Consequently, it is } \\
\text { expected that settlements with patients will not be } \\
\text { reimbursed by insurers and that this will have an } \\
\text { adverse impact on cash flow of a proximately } £ 40 \mathrm{~m} \\
\text { during } 2005 \text { (Smith and Nephew plc, Annual } \\
\text { Report 2004) }\end{array}$ & Operational risk & $\begin{array}{l}\text { Future/qualitative/bad } \\
\text { Future/quantitative/bad }\end{array}$ \\
\hline
\end{tabular}

